STUDIA NORWIDIANA 38:2020

DOI: https://doi.org/10.18290/sn.2038-5

KAROL SAMSEL

SPÓR O FILOZOFIĘ SZATY. CYPRIAN NORWID A THOMAS CARLYLE

Po długiej przerwie (w związku z kolejnymi recenzjami oraz omówieniami Kalendarza życia i twórczości Cypriana Norwida) powraca - czy raczej ma szansę w obręb norwidologii powrócić - zapoznana już od jakiegoś czasu paralela między systemem estetycznym i antropologią Cypriana Norwida oraz filozoficznym poglądem na świat Thomasa Carlyle'a. Z jednej strony Elżbieta Lijewska redukuje najbardziej zasadniczy trop dla badania wpływów, jakie Carlyle mógł w ogóle wywierać na Norwida. Czyni to, słusznie wskazując na pomyłkę zawartą w Kalendarzu..., dotyczącą tożsamości niejakiej Katherine Kitty Kierkpatrick korespondującej z Norwidem, postrzeganej do tej pory jako kochanka Carlyle'a z czasów pisania przez niego Sartor Resartus. Tajemnicza Kierkpatrick to bowiem najprawdopodobniej kuzynka Norwida, Ketty Kleczkowska-Kierkpatrick ${ }^{1}$.

Z drugiej jednakże strony Bogdan Burdziej przywołuje, a także uważnie rozpatruje kontekst listu Mariana Sokołowskiego do Norwida z 10 lipca 1861 r. dotyczący Wykładów o Juliuszu Stowackim. Sokołowski miał tu „porównać cechy stylu i myśli poety z tekstami Thomasa Carlyle'a i Percy Bysshe Shelleya”². Zdaniem Burdzieja, „sposób, w jaki Sokołowski formułuje swoją opinię («Przypominasz wtedy niektóre abstrakcyjne urywki Thomasa Carlyla [...]») świadczy o jego przekonaniu, że Norwid ma wystarczającą znajomość dzieł obu angielskich autorów, by w pełni zrozumieć porównanie, jakie czyni nadawca listu"3. Jak w związku z tym podejrzewa Burdziej, „Norwid [przykładowo - K.S.] mógł zetknąc się z Carlyle'em jako autorem wstępu do esejów R.W. Emersona, które-

${ }^{1}$ E. LiJewsKA, Kuzynki Norwida. Euphemia Tudor Kleczkowska i Ketty Kleczkowska-Kierkpatrick, „Studia Norwidiana” 34: 2016, s. 169-185.

${ }^{2}$ B. BurdZIEJ, ,,Wedle rozmaitości zmiennej kalendarza”. Norwid „,przemyślony”, „Studia Norwidiana" 34: 2016, s. 203.

${ }^{3}$ Tamże. 
go pisma prawdopodobnie znał"4. Warto na marginesie podkreślić, że poszukiwania Burdzieja wpisują się w panoramę cennych dywagacji Stanisława Brzozowskiego. To on bowiem w Legendzie Młodej Polski, jako pierwszy, postulował paralelę Norwid - Carlyle:

Prawdziwie pożytecznego dzieła dokonałby ten, kto by zechciał pracować na rozbudzeniem i rozkrzewieniem u nas „historycznej namiętności”, przez którą pojmuję miłość i cześć dla wszystkich dzieł i procesów zbiorowego życia ludzkiego trwaniem swym o wiele przekraczającym zakres indywidualnego istnienia. Trzeba hodować i ćwiczyć to poczucie i zamiłowanie wielkich ponadindywidualnych rytmów. Vico, Michelet, Carlyle wydają mi się pisarzami najodpowiedniejszymi do odegrania takiej roli dziejowych inicjatorów. Dobre, komentarzem opatrzone wydanie Norwida - byłoby też nieocenione pod tym względem ${ }^{5}$.

Zdaniem autorek Kalendarza życia i twórczości Cypriana Norwida, Norwid czyta dzieła Ralpha Waldo Emersona (jego eseje bądź też traktat Representative Men) dopiero w latach 1853-1854 ${ }^{6}$. Możliwe reminiscencje z lektur pism Carlyle’a

${ }^{4}$ Tamże.

${ }^{5}$ S. Brzozowski, Literatury zachodnie, [w:] Tenże, Legenda Młodej Polski. Studia o strukturze duszy kulturalnej. Redakcja II, t. I: opracowanie tekstu: J. Bahr, współpraca: S. Góra, t. II: opracowanie tekstu: T. Podoska, Kraków 1997, s. 286. Warto zauważyć pozostawione całkowicie in potentio, niezwykle subtelne zastrzeżenia, jakie w niniejszym fragmencie Brzozowski formułuje. Warunkiem, ażeby Norwid pojawił się rzeczywiście obok Vica, Micheleta i Carlyle'a, będzie dobre wydanie oraz dobry komentarz. Podobnych skrupułów nie wolno w Legendzie Młodej Polski lekceważyć. Norwid wcale nie jest dla Brzozowskiego pierwszym - względem Carlyle’a - partnerem dialogu kulturalnego. Dość tu powiedzieć, że sam Brzozowski jest - gdy mowa o wyłanianiu polskich dla Carlyle'a adherentów - szalenie niekonsekwentny. Albo bowiem twierdzi, że nie ma nikogo, kto zasługiwałby na miano „polskiego Carlyle'a”, jak pisze w Polskim Oberammergau: „W polskiej literaturze przy jej dotychczasowym charakterze nie daje się pomyśleć ani Hebbel, ani Balzak, ani Kleist, ani Carlyle, ani Machiavelli”, albo - na „polskiego Carlyle'a” wysuwa wyłącznie jedną, wyróżnioną osobę - jest nią (w Wobec literatury rosyjskiej) Stanisław Wyspiański: „W stosunku do swego społeczeństwa jest Dostojewski tem, czem był Carlyle dla Anglików, Carducci dla Włochów, Wyspiański dla nas". Norwid w podobnych wyliczeniach - w bliskim sąsiedztwie Carlyle'a raczej się nie pojawia. S. Brzozowski, Polskie Oberammergau, [w:] Legenda Młodej Polski, t. I, s. 181, oraz TENŻE, Wobec literatury rosyjskiej, [w:] Legenda Młodej Polski, t. II, s. 349.

${ }^{6}$ Z. TROJANOwiczowa, Z. DAMBEK, Kalendarz życia i twórczości Cypriana Norwida, t. I: 1821-1860, Poznań 2007, s. 549. W norwidologii dominuje przekonanie, że Norwidowski etos wielkości osób historycznych - jeśli szukać dla niego w ogóle globalnych zapośredniczeń czerpał raczej z Emersonowskiego Representative Men aniżeli z Carlyle'owskiego traktatu Bohaterowie. George Gömöri zauważa: „There could be certain things which linked Norwid to Emerson. They were both Abolitionists and both believed in the special destiny of «representative individuals»”. G. Gömöri, Cyprian Norwid's Image of England and America, „The Polish Review" 2001 vol. 46 no. 3, s. 279. Pogląd Carlyle'a w tym względzie musiał uchodzić za 
sięgać mogą wszakże już Promethidiona. Tam Wiesław z drugiego dialogu utworu wypowiada się niejako w kontrze do poglądów Diogenesa Teufelsdröckha, bohatera oraz głównego ideowego protagonisty powieści Sartor Resartus, wyimaginowanego i wykoncypowanego twórcy filozofii szaty ${ }^{7}$ : „Czar papieży / Ile z zewnętrznej pochodzi przyczyny / Z szat drogich, pawich piór i pajęczyny / Koronek - również do niego [szatana - K.S.] należy -" (DW IV, 126).

Jak objaśnia ten ustęp Promethidiona Norwid:

Nie idzie tu i w całym zewnętrzności pojęciu o zdarcie drogości, świetności, błyskotności, ale o proporcję ich z powagą wewnętrzną, rzeczywistą - ale o strawienie ich na sobie powagą życia - bo i tak duch ma dosyć ciężaru w szacie ciała!... Na cóż go jeszcze obciążać ciałem szaty?... (DW IV, 126)

Dość wyraźnie może tu zarysowywać się polemika Norwida z rozdziałem szóstym księgi trzeciej Sartora Resartusa:

Z tém większą radością składam z drugiéj strony uszanowanie owym Skorupom i Łuskom Ciała, w których dłużéj żadna diabelska namiętność nie przebywa, ale które są jedynie czystemi godłami i podobiznami Człeka - mam w myśli Próżne, odrzucone Suknie. Ach! czyż najwięcej ludzi nie oddaje zawsze ukłonów Sukniom - pięknie wyprasowanéj sajecie, nie zaś „rozszczepionemu zwierzęciu z koszlawemi nogami”, którego sajeta w sobie zawiera, czyniąc go Dygnitarzem? Kto kiedy słyszał, żeby milordowano Lorda w podartéj kołdrze, zapiętéj drewnianym rożenkiem? Powiadam jednak, że w takiém nabożeństwie tai się często cień obłudy, praktyczne złudzenie, bo Ciało przywłaszcza sobie cześć przeznaczoną jedynie Suknu! ${ }^{8}$

proniewolniczy, o czym świadczył esej z 1849 r. Occasional Discourse on the Negro Question i spór pisarza z Johnem Stuartem Millem, który zareagował na tekst Carlyle'a tekstemodpowiedzią w 1850 r.: The Negro Question.

${ }^{7}$ Bardzo ważną pracą na temat znaczenia filozofii szaty i jej oddziaływania na Polaków oraz mody umysłowe tzw. polskiego modernizmu jest synteza Anny Małeckiej, Carlylean inspirations in Polish modernist philosophy, Kraków 1993.

${ }^{8}$ T. CARLYLE, Sartor Resartus. Życie i zdania Pana Teufelsdröckha $w$ trzech księgach, przeł. S. Wiśniowski, Warszawa 1882, s. 183. „The gladder am I, on the other hand, to do reverence to those Shells and outer Husks of the Body, whereim no devilish passion any longer lodges, but only the pure emblem and effigies of Man: I mean, to Empty, or even to Cast Clothes. Nay, it is not to Clothes that most men do reverence: to the fine frogged broadcloth, nowise to the «straddling animal with bandy legs» which it holds, and makes a Dignitary of? Who ever saw any Lord my-lord in tattered blanket fastened with wooden skewer? Nevertheless, I say, there is in such worship a shade of hypocrisy, a practical deception: for how often the Body appropriate what was meant for the Cloth only!" (T. CARLYLE, Sartor Resartus. On heroes, hero worship, introduced by W.H. Hudson, London 1948, s. 180). 
Sartor Resartus spisywany przez Carlyle'a między listopadem 1833 a sierpniem 1834 r. jest - jak można by rzec - sparodiowaną powieścią romantyczną wpisaną w sparodiowany, idealistyczno-historiozoficzny traktat. Narratorem całości jest przybywający do domu Diogenesa Teufelsdröckha recenzent, który mimo zażyłości, jaka go z tamtym łączy - nie jest w stanie zrozumieć powodów, dla których Teufelsdröckh zdecydował się stworzyć ekstrawagancki traktat o filozofii szaty i (mówiąc za Heglem) „fenomenologii” stroju oraz ubierania się. W miarę, jak narasta sympatia edytora dla szalonego pomysłu ,idealisty ubioru”, perspektywa zrecenzowania jego opus magnum oddala się, czytelnikowi całości natomiast - coraz wyraźniej - uwidoczniona zostaje perspektywa przeszłego życia ekscentryka, które ostatecznie doprowadziło go do na pozór godnego politowania „tu i teraz”. W kontekście gry z paradygmatem preromantycznym najważniejsze w Sartorze Resartusie wydaje się zauroczenie nieszczęśliwego mężczyzny Bluminą (możliwy pierwowzór Kierkpatrick), która ostatecznie wybiera jednak nie Teufelsdröckha, ale doskonale sytuowanego Towgooda. Fabuła u Carlyle'a posiada (jak widać) charakter szczątkowy, tym wszelako, co przesądza o realnej wartości całości tekstu, jest jego osobliwa traktatowość. Z zawiązania akcji wydarzeń najważniejsza pozostaje bowiem ostateczna motywacja całej sytuacji zastanej przez recenzenta $\mathrm{w}$ prologu opowieści: $\mathrm{z}$ banalnej, werterowskiej historii ujmowanej na dodatek w krzywym zwierciadle zrodził się oto bodziec dla temperamentu intelektualnego Teufelsdröckha, ten z kolei - bez zahamowań dał mu upust, stwarzając absurdalny (a jednocześnie zachwycający) pseudo-heglowski traktat o ubiorze.

O ile w bogatym tak czy inaczej horyzoncie znaczeń Promethidiona warto zaryzykować tezę o istnieniu temperamentu polemicznego Norwida względem Sartora Resartusa Carlyle'a, temperamentu wyraźnie negatywnie na Carlyle'u zogniskowanego, a wręcz ,gestu zaprzeczenia i sprzeciwu”, o tyle w późniejszym o trzy dekady kręgu tzw. nowel włoskich Carlyle zdaje się u Norwida powracać (dodajmy, że w znaczącym momencie, bowiem niedługo zaraz po swojej śmierci w 1881 r.) jako przedmiot „zaszyfrowanej” afirmacji. W szczególny sposób to Tajemnica lorda Singelworth może się jawić jako realny powrót do rozliczeń z filozofią szaty obecną w jednej z istotniejszych dygresji Promethidiona. Otóż, ekscentryczny lord-aeronauta wydaje się modelowany właśnie na wzór Diogenesa Teufelsdröckha, jeszcze z Sartora. Jego „ekcentryzmy” z kolei mogą przypominać „ekcentryzmy” samego czterdziesto-, pięćdziesięcioletniego Carlyle'a - tak jak zapamiętał go istotny chyba dla Norwida Ralph Waldo Emerson.

Rzecz jasna, dyskusje nad tożsamością Lorda Singelworth obrosły już licznymi komentarzami, których nie sposób w tym momencie ani wyliczyć w pełni, 
ani uchylić - dość wspomnieć, że w jednym z ostatnich tekstów na ten temat Tajemnicach „,Tajemnicy lorda Singelworth” Zofia Dambek-Giallelis wskazywała na możliwą inspirację Norwida postacią Dionizosa Solomosa z Podróży do Ziemi Świętej z Neapolu właśnie przez wzgląd na podobieństwo dwóch (realizowanych przez Słowackiego i Norwida) modeli „twórczych ekscentryczności”. Pisała:

W personie Singelwortha najciekawsza jest jej wystudiowana ekscentryczność, która ma uchodzić za naturalną: unikanie towarzystwa, kompulsywne pragnienie czystości, odgradzanie się od świata; te cechy przypominają portret poety, który Norwidowi mógł zapaść w pamięć. Chodzi o ironiczną charakterystykę greckiego poety Dionizosa Solomosa z Podróży do Ziemi Świętej z Neapolu Juliusza Słowackiego. Możemy założyć, że Norwid czytał najpewniej poemat Słowackiego ogłoszony w wydaniu pism pośmiertnych Antoniego Małeckiego w $1866 \mathrm{roku}^{9}$.

Wyróżniona, „wystudiowana ekscentryczność” - tak dla Dambek-Giallelis zajmująca, odbijająca się także w innych studiach norwidologicznych: w porównywaniu (1) Singelwortha z Byronem (Grażyna Halkiewicz-Sojak ${ }^{10}$ ), lub (2) z którymś z jego bohaterów-dandysów (zestawienie noweli Norwida z weneckim poematem Beppo; Krzysztof Trybuś ${ }^{11}$ ) - jest pod względem wyraźnej symetrii typów również „wystudiowaną ekscentrycznością" Carlyle’a, zwłaszcza podawanego w przekazie Emersonowskim, wedle litery najsłynniejszego chyba studium o Carlyle'u, które Norwid mógł rzeczywiście znać - Impressions of Thomas Carlyle in 1848. Pora na garść cytatów stamtąd:

1. Jest on także jedną z osobliwości Anglii... jak Tower londyński, ale nie zadawala cudzoziemców.

2. Chowają go w Anglii jako przenośny dzwon katedralny i lubią go pokazywać w towarzystwach, gdzie nie był znany, żeby rozkołysany i rozdzwoniony zdumiewał i przerażał takie osoby jak biskupów, dworzan, uczonych i literatów.

3. Ludzie wszelkiego stanu hołdują mu z ostentacyjną pokorą. On téż ceni swą wartość i nie bywa w towarzystwach pod innemi warunkami, jak podyktowanemi przez siebie.

4. Jeślibyście chcieli mieć dokładne pojęcie, jak przemawia, wyobraźcie sobie, że Hugh Whelan (ogrodnik) znalazł dość wolnego czasu do przeczytania Platona i Szekspira, św. Augustyna i Kalwina, ale zostawszy wciąż Hughem Whelanem, wyraża się z gorzką pogardą o tym całym nonsensie książkowym, którym sobie musiał głowę kłopotać.

${ }^{9}$ Z. DAmbeK-Giallelis, Tajemnice „,Tajemnicy lorda Singelworth”, „Studia Norwidiana" 35: 2017, s. 195.

${ }^{10}$ G. HALKIEWICZ-SOJAK, Norwidowska legenda o Byronie. Refleksy legendy w innych utworach Norwida, [w:] TAŻ, Byron w twórczości Norwida, Toruń 1994, s. 112-113.

${ }^{11}$ K. TRYBUŚ, Maska lorda Singelworth, „Studia Norwidiana” 14: 1996, s. 101. 
5. Nazwałem go raz młotem parowym z dodaną arfą eolską ${ }^{12}$.

Rzecz jasna, Singelworth był lordem, Carlyle zaś w opinii Emersona, ale nie tylko jego, ,praktycznym Szkotem, jakich spotykacie w warsztatach siodlarskich lub téż w handlach żelaznych, a potém dopiéro, skutkiem nadzwyczajnego wypadku, był cudownym i uczonym autorem" ${ }^{\prime 3}$. Nie należy jednak zapominać, że co do enigmatycznego tytułu lordowskiego Norwidowskiego protagonisty także wysuwano daleko idące obiekcje. „Czyli raczej Singelworthowie byli zacnymi właścicielami rękodzielni wyrabiających perkaliki albo rzeczy cynowe i stalne?..." (DW VII, 219) - zapytuje (równie przewrotnie, co i retorycznie) już w piątym zdaniu noweli narrator, a pytanie ma w sobie wymiar nośnika i medium tytułowej tajemnicy „wystudiowanej ekscentryczności” lorda (albo-nielorda) aeronauty. Gwoli potrzebnego tu wyjaśnienia - James Carlyle, ojciec Thomasa był kamieniarzem, jego druga żona zaś, a zarazem matka autora Sartora Resartusa - córką zbiedniałego farmera przybitego utratą majątku w Dumfriesshire ${ }^{14}$.

Singelworth w podróży balonem przez wszystkie stolice Europy dokonuje wiwisekcji nowoczesnej cywilizacji. Tak jak Carlyle, jest przy tym bezlitosnym mordercą wielu „nowoczesnych złudzeń”. „W końcu dowcip zjadliwy i ognista mowa uczyniła go wszędzie pożądanym, a dla wszystkich strasznym autorem

\footnotetext{
${ }^{12}$ W przekładzie Sygurda Wiśniowskiego, Charakter i pisma Tomasza Carlyle’a, „Ateneum. Pismo naukowe i literackie" 1(1882), s. 55.

${ }^{13}$ Tamże.

${ }^{14}$ Zrodzony z „rodziców wieśniaków” - jak pisze o nim Wiśniowski - miał Carlyle za ojca „rolnika i partacza mularskiego”. S. WiśniOwsKi, Tomasz Carlyle, [w:] T. CARLYLE, Sartor Resartus, s. 5. Dotykamy w tym punkcie samego sedna sporu pomiędzy Carlyle'em a transcendentalistami amerykańskimi, a zwłaszcza Ralphem Waldo Emersonem (co pośrednio uwidoczniają Impressions of Thomas Carlyle in 1848). Jest to spór między plebeistami a arystokratystą, spór „dżentelmena z Nowej Anglii” (określenie Stefana Bratkowskiego) oraz „krytycznego Szkota chłopskiego pochodzenia" (określenie Sygurda Wiśniowskiego). Co do Emersona, ,po pierwszym okresie błądzenia po różnych indywidualizmach [...] filozofia ta nie miała później w sobie nic z arystokratyzmu Carlyle’a, Spencera czy Nietzschego. Była ze swej istoty i przeznaczenia - plebejska. Emerson adresował ją do milionów swoich rodaków, do milionów amerykańskich self-made-manów”. S. BRATKOWSKI, Wstęp, [w:] R.W. EMERSON, Eseje, przeł. A. Tretiak, wstęp S. Bratkowski, t. I, Lublin 1997, s. 21. Jeżeli Tajemnica lorda Singelworth wydaje się zdradzać oddziaływanie na Norwida Carlyle'owskiego arystokratyzmu, możliwy wpływ plebeizmu Emersona (i być może wpływ wierszy Walta Whitmana) ujawnia A Dorio ad Phrygium. Zob. więcej: F. CORLISS JR., Norwid and the American Transcendentalists, [w:] Cyprian Norwid. 1821-1883. Poet, thinker, craftsman. A centennial conference, ed. by B. Mazur and G. Gömöri, London 1988, s. 74-75.
} 
i gościem"15, to o Thomasie Carlyle'u - Szkocie wzbudzającym popłoch wśród Anglików - pisał Sygurd Wiśniowski, jego popularyzator w Polsce oraz thumacz Sartora Resartusa. Gdzie indziej triumfująco orzekał (uprzedzony do Anglików): „w téj Anglii trzymał się syn kmiecy hardo, zmusił modny, bogaty i potężny świat drżéć przed sobą" ". U Norwida obelżywość Singelwortha zostaje ledwie zaznaczona, lecz i tak uderza sugestywnością, szczególnie gdy „Europejczyków kontynentalnych" zestawia on z Murzynami, bo ,ze wszystkiego się śmieja, czego od razu pojać nie sq w stanie..." (DW VII, 229) lub - perorując o dualizmie dobra oraz zła, w który wciąż zapatrzona jest Europa - stwierdza: „tak jest w ludziach, jak u niektórych pokoleń na Kaukazie” (DW VII, 230) ${ }^{17}$. Wyjątkowe prawo oskarżenia Singelworth uzurpuje wręcz sobie z przekonania, że - jako jedyny lub jeden z niewielu - „spogląda w dół” wszelkiej kultury i cywilizacji, czyniąc to (z konieczności) z wyższością - spogląda bowiem w dół gnilny.

Owa perspektywa ostrej, apodyktycznej, osądzającej wszystko panoramy jest nieodłączna także w refleksjach i medytacjach Teufelsdröckha z Sartora... Tak jak Singelworth zaprawiał się w spojrzeniu na wszystko z góry w balonie, Teufelsdröckh korzystał z kwatery na wzniesieniu, która „była tedy - jak relacjonuje nam rzecz Wiśniowski - rodzajem zwierciadła i strażnicy" (the speculum or watch-tower $)^{18}$. I Wiśniowski kontynuował: „siedząc sobie wygodnie, można było stamtąd przyglądać się tętniącemu życiu znacznego miasta, którego prawie wszystkie ulice i zaułki roztaczały się w dole jak na talerzu" ${ }^{\prime 19}$. Zestawmy odpowiednie fragmenty:

\footnotetext{
${ }^{15}$ S. WiŚniOWSKI, Tomasz Carlyle, s. 7.

${ }^{16}$ Tamże, s. 8.

${ }^{17}$ Zachowanie Singelwortha mogące sugerować rasizm lub szowinistyczne, narodowe uprzedzenia (Europa kontynentalna, Murzyni, Kaukaz) daje się wytłumaczyć poprzez biografię Carlyle'a, zwłaszcza w świetle jego wystąpienia Occasional Discourse on the Negro Question. To kolejny argument na rzecz przedstawianej tutaj hipotezy, że Norwid modeluje Singelwortha (razem z jego idiosynkrazjami, a właściwie - przede wszystkim z nimi) na podobieństwo Carlyle'a. Zob. przypis 5.

${ }^{18}$ T. CARLYLE, Sartor Resartus. On heroes, s. 14.

19 „Wherefrom, sitting at ease, he might see the whole life-circulation of that considerable City; the street and lanes of which, with all their doing and driving (Thun and Treiben), were for the most part visible there", tamże.
} 
KAROL SAMSEL

\begin{tabular}{|c|c|}
\hline $\begin{array}{l}\text { C. Norwid, Tajemnica lorda } \\
\quad \text { Singelworth }\end{array}$ & T. Carlyle, Sartor Resartus \\
\hline $\begin{array}{l}\text { „Tymczasem miasta wasze, siedziby } \\
\text { i społeczności sklepią się, budują i rozwi- } \\
\text { jaja na kloakach... Te wykwintne kuch- } \\
\text { nie, które co dnia pod wieczór buchają } \\
\text { aromem wonnych przypraw i sosów, } \\
\text { maja pod posadzkami swoimi trzęsawiska } \\
\text { zgnilizny - te ponętne błyskotem swym } \\
\text { i elegancją salony, gdzie równie lekki jak } \\
\text { zefir trzewik tanecznicy walcuje z zefi- } \\
\text { rem, one są usklepione na podziemiach } \\
\text { ciężkich i odrażających. Leniwe tam } \\
\text { ramię rozkładającego się olbrzyma prze- } \\
\text { ciąga się, ale nieustającą walkę co dnia } \\
\text { i co chwila toczy - coś, jakby wciąż gni- } \\
\text { jacy Laokoon, przewraca się w piecza- } \\
\text { rach stolic pod umiecionymi gładko uli- } \\
\text { cami!...” [podkreślenia moje - K.S.]. } \\
\text { (DW VII, 230) }\end{array}$ & $\begin{array}{l}\text { „Lubię puszczać oko w ten dół, na to } \\
\text { gniazdo os lub ul pszczelny - rzekł raz } \\
\text { profesor w naszéj obecności - i być } \\
\text { świadkiem, jak się tam wosk układa, } \\
\text { miód robi, trucizna warzy, owady duszą } \\
\text { się wyziewami siarki. Widzę wszystko, } \\
\text { od Pałacowego dziedzińca, na którym } \\
\text { przygrywa muzyka, podczas gdy Jego } \\
\text { Jasna Wysokość raczy spożywać jadło, } \\
\text { do podłego zaułka, w którym siedzi na } \\
\text { progu staruszka wdowa, robiąca pończo- } \\
\text { chę dla zaspokojenia głodu i ciesząca się } \\
\text { słonkiem popołudniowém”. „Twardy } \\
\text { bruk jest Obrazem Zmysłów. Kroczą po } \\
\text { łonie Nicości. Czas podobny do czarnéj, } \\
\text { szerokiéj tablicy ciągnie się za niemi } \\
\text { i przed niemi”. „Ach, dziwna to Kadź } \\
\text { rozczynu, co się burzy i ukrywa pod tą } \\
\text { powłoką ze zgniłych wyziewów, z gazów } \\
\text { niezliczonych”. }\end{array}$ \\
\hline $\begin{array}{l}\text { „Odpowiednia doza perfum gdy staje } \\
\text { w przeciwieństwie zględem dozy odpo- } \\
\text { wiedniej rozkładowego fetoru, jest to dla } \\
\text { was czystym oddechem, bo taki już macie } \\
\text { nerwów ustrój”. ,- Ludzie nie sa jeszcze } \\
\text { czyści... sq dopiero perfumowani...” (DW } \\
\text { VII, 230, 232) }\end{array}$ & $\begin{array}{l}\text { „Dumny magnat zabawia się jeszcze } \\
\text { w perfumowanych salonach lub spoczął } \\
\text { już za adamaszkową firanką; nędza kur- } \\
\text { czy się na pryczy lub drży od chłodu } \\
\text { i głodu w słomianym barłogu”,20. }\end{array}$ \\
\hline
\end{tabular}

${ }^{20}$ Cytaty w obu wierszach tabeli: TENŻE, Sartor Resartus. Życie i zdania, s. 26-27.

Wiersz pierwszy: „«I look down into All that wasp-nest or bee-hive», have we heard him say, «and fitness their wax-laying and honey-making, and poison-brewing, and choking by sulphur. From the Palace esplanade, where music plays while Serene Highness is pleased to eat his victuals, down to the low lane, where in her door-sill the aged widow, knitting for a thin livelihood, sits to feel the afternoon sun, I see it all»”. „Their solid Pavement is a Picture of the Sense; they walk on the bosom of Nothing, blank Time is behind them and before them”. „Oh, under that hideous covelet of vapours, and putrefactions, and unimaginable gases, what a Fermenting-vat lies simmering and hid!”, TENŻE, Sartor Resartus. On heroes, s. 14, 15. Wiersz drugi: „The proud Grandee still lingers in his perfumed saloons, or reposes within damask curtains; Wretchedness Cowes into truckle-beds, or shivers hunger-stricken into its lair of straw", tamże, s. 15-16. 
W dyskusji nad podobieństwami Tajemnicy lorda Singelworth oraz Sartora Resartusa najbardziej być może intrygująca, a zarazem nieoczywista jest podobna stylizacja języka wypowiedzi lorda Norwida i profesora Carlyle'a, mogąca przypominać mowę archaizowaną, argotyczną czy wręcz kreolizowaną. Teufelsdröckh przemawia bowiem, wykorzystując angielski jak plastyczny materiał mowy, który można, a wręcz należałoby... upodobnić do swojego języka pierwszego. Oznacza to, że wybiera dokładnie te formy archaicznego angielskiego, które kojarzą mu się z Prusami, (,thee” jak „die”, „couldst” jak ,hast” itd.) tak jak gdyby (z cudzoziemska) germanizował, „familiaryzował” on język, zadomawiał się w nim, gdy de facto specyficznie go archaizuje sformułowaniami takimi, jak ,the thing thou seekest is already with thee, 'here or nowhere', couldst thou only see!”,21, „nay, in thy own mean perplexities, do thou thyself, but hold thy tongue for one day, ${ }^{22}$, ,were it but the pitifullest infinitesimal fraction of a Product" ${ }^{23}$. Norwidowski Singelworth dla odmiany przemawia tak, jak gdyby po sarmacku makaronizował, posługując się rozwlekłą i ,pogubioną” składnią, niemal zawsze do tego celując mimowolnie w swoim krótkim monologu w błąd gramatyczny. Dosyć wziąć tu za przykład jedno „scjentyfikowane” zdanie:

Lecz u tychże tak łatwo śmiejących się jest w zamian piękne uczucie poważania z wielką łatwością donośnych imion historycznych; będę więc umiał choć tym sobie posłużyć i pomóc na swoim miejscu, kiedy, w zupełny wykład celu mojej aeronaucji zapuściwszy się, napotkam gdzie trudności, na uprzedzający śmiech zwykłe wykładającego rzecz nową narażać.

(DW VII, 230)

Także w Tajemnicy lorda Singelworth Norwid zdaje się powracać do Carlyle'owskiej filozofii szaty, od której zapoczątkować miał swój spór z genialnym Szkotem w Promethidionie. Czyni to jednak nie za pośrednictwem bohatera tytułowego, mogącego być agregatem cech zarówno Diogenesa Teufelsdröckha, jak i samego Thomasa Carlyle'a, lecz poprzez Toniego di Bona Grazię, weneckiego improwizatora, który podsuwa swoim słuchaczom myśl o wejrzeniu w śmietnik jako jedynym i ,nieuchylanym” warunku rozpoznania reguły dziejowej w świecie, w którym - jak wskazywał w Nędznikach Wiktor Hugo, na co kładł nacisk

${ }^{21}$ T. CARLYLE, Sartor Resartus. On heroes, s. 148.

${ }^{22}$ Tamże, s. 164.

${ }^{23}$ Tamże, s. 148. Podejrzenia Stanisława Brzozowskiego z kolei wywoływała w Legendzie Młodej Polski poszarpana składnia Sartora Resartusa. Dziwił się jej i spekulował na temat jej znaczenia, ostatecznie stwierdzał nawet: „Carlyle pisze Sartora Resartusa, niemal autoparodię, Nietzsche - Zaratustrę - dytyramb". S. BRZOZOWSKI, Humor i prawo, [w:] TENŻE, Legenda Młodej Polski, t. I, s. 294 i w różnych miejscach. 
w kontekście Tajemnicy lorda Singelworth Krzysztof Trybuś - „ścieki to sumienie miasta”, „kupa śmieci ma tę zaletę, że nie kłamie”24.

Paralela z Nędznikami jest w kontekście Norwida w istocie frapująca, nie trzeba jednak wcale zapominać o Sartorze Resartusie. Wskazują na niego eksponowane przez improwizatora ,atłasowy trzewik, konwulsyjnie skręcony, opierający się na stłuczonej butelce” czy „guzik munduru wojskowego, przeświecający spod szczątków miotły". Tak u Norwida, jak i u Carlyle'a symbole tego rodzaju - znaki i szczątki „szat” - wyposażone zostają w rozległy horyzont historycznoeschatologiczny. W Sartorze miejsce Norwidowskiego „trzewika” i „guzika mundurowego” zajmują barwne „kołki do wieszania sukni”, „ostrogi u obcasów” i ,pióro na czubie":

\begin{tabular}{|c|c|}
\hline C. Norwid, Tajemnica lorda Singelworth & T. Carlyle, Sartor Resartus \\
\hline $\begin{array}{l}\text { „[...] o! świetna publiczności... jakkolwiek } \\
\text { bowiem wy! - lubo słusznie - odwracacie } \\
\text { oczy wasze od śmietników, mnie zdarzało } \\
\text { się w głębokim zadumaniu nad nimi stawać } \\
\text { i odczytywać dzieje godzin ubiegłych z tych } \\
\text { okrytych kurzawą palimpsestów! - Tu były- } \\
\text {-atłasowy trzewik, konwulsyjnie skręcony } \\
\text { i opierający się na stłuczonej butelce - tam } \\
\text { guzik monduru wojskowego przeświecający } \\
\text { spod szczątków miotły - ówdzie siódemka- } \\
\text {-czerwienna, as treflowy i wizytowa karta, } \\
\text { połamane... dalej fiołków bukiet, który oto } \\
\text { błędna i nie dowierzająca kotka wącha... } \\
\text { w pobliżu kałamarz pusty i nadużyte pióro, } \\
\text { nieudolnie silące się podrywać z powianiem } \\
\text { wiatru!... Szczątki te śmietnicze opowiadały } \\
\text { mi były nieraz długie i zawiłe przypowieści } \\
\text { - kto wie, azali Muza moja nie była kiedyś } \\
\text { szyfonierką?!...”. (DW VII, 223) }\end{array}$ & $\begin{array}{l}\text { „Może ci się wydaje, że ten tam czer- } \\
\text { wony i żółty kołek do wieszania sukni, } \\
\text { mający ostrogi u obcasów i pióro na } \\
\text { czubie, jest tylko istotą Dnia dzisiej- } \\
\text { szego, bez Wczora i Jutra? Nie miałże } \\
\text { on żywego przodka jeszcze, gdy } \\
\text { Hengst i Hora najechali twą wyspę? } \\
\text { Przyjacielu, poznaj w nim oczko } \\
\text { w tkaninie Dziejów oblekającéj } \\
\text { Wszechjestestwo i bacz uważnie, jak } \\
\text { ono wygląda, zanim się przesunie } \\
\text { i zniknie na zawsze"25. }\end{array}$ \\
\hline
\end{tabular}

\footnotetext{
${ }^{24}$ V. HugO, Nędznicy, przeł. K. Byczewska, t. IV, Warszawa 1980, s. 157. Zob. także: K. TRYBuŚ, Maska lorda Singelworth, s. 101-102.

${ }^{25}$ T. CARlyle, Sartor Resartus. Życie $i$ zdania, s. 26. „Or fanciest thou, the red and yellow Clothes-screen yonder, with spurs on its heels and feather in its crown, is but of Today, without a Yesterday or a Tomorrow; and had not rather its Ancestor alive when Hengst and Horsa overran thy Island? Friend, thou seest here a living link in that Tissue of History, which inweaves all Being: watch well, or it will be past thee, and seen no more", TENŻE, Sartor Resartus. On heroes, s. 15.
} 
Zestawiając Tajemnice lorda Singelworth i Sartora Resartusa po raz pierwszy, podkreśliłem w tabeli te fragmenty z Norwida, które mogły uprawnić swego czasu Wiktora Weintrauba do sformułowania kategorycznego o całej noweli sądu. Badacz mówił o poecie, że „poprzez skatologiczny humor dał ujście ostrej mizantropii" ${ }^{26}$. Najwyraźniej pozostawał poruszony wytropionym i nazwanym przez siebie precedensem: „Do tej pory poczucie decorum Norwida było nieskazitelne i jego styl elegancki, wyrafinowany, daleki od wszelkiej wulgarności”27.

Odczucia autora studium Norwid i Ameryka (bo o tym tekście tu mowa) nie były w moim przekonaniu przypadkowe. Miały nie tylko swoje źródło, lecz także - początek (jak uważam) w twórczym zamyśle, intencji - rywalizacji z Carlyle'em jako autorem Sartora Resartusa. Pragnienie tej rywalizacji wzmogło się czy też mogło się wzmóc wraz ze śmiercią Szkota 5 lutego 1881 r. w Londynie. To kolejne $\mathrm{z}$ wielu wydarzeń, które należałoby dołączyć do skomplikowanej genealogii mającej powstawać w latach 1881-1883 „trylogii włoskiej”.

Zwróćmy bowiem na koniec uwagę na dwuczłonowość nazwisk obu protagonistów Norwida i Carlyle'a. „Single-worth” to rzecz o jednej, ustalonej wartości czy też wartość pojedyncza. „Dio-genes Teufels-Dröckh” to - jak thumaczy w studium Carlyle's Political Religion Richard J. Bishirjian - „Man's origin is in God, and his existence is the devil's feces"28, a więc - swobodnie thumacząc jesteśmy z Boga, Bóg rodzi się w nas każdego dnia, lecz tu na ziemi - tkwimy w kale diabła (inne spotykane wśród badaczy określenie Teufelsdröckha to „God-born devil's excrements" ${ }^{29}$ ).

Norwid o tym specyficznym, Carlyle'owskim anagramie mógł pamiętać w wielu momentach własnej twórczości, począwszy od najbardziej znanej w tym wypadku frazy z Idei i prawdy („I nieraz szczytne wczorajszego wieka / Dziś tyczy kału...”, PWsz II, 66) przez dłuższe formy, jak próba teorii prawdy z Rzeczy o wolności słowa („Zniżona tak, zaczerpnie namiętności kału, / Potem się wyprze ojca swego... Ideału!", DW IV, 248) czy stosunkowo najmniej znane frazy z dramatów, jak tyrada Rizzia z Hrabiny Palmyry (,ludzie, co tworzą dla ludzi” „wlec się powinni w kale jak spadłe anioły”, DW V, 316). Wszystkie gnomy tego rodzaju poddają się u Norwida specyficznemu, „rozjaśniającemu”

\footnotetext{
${ }^{26}$ W. WeInTRAuB, Norwid i Ameryka, „Studia Norwidiana” 14: 1996, s. 17.

${ }^{27}$ Tamże.

${ }^{28}$ R.J. BishiRJiAn, Carlyle's Political Religion, „The Journal of Politics” 38(1976), no. 1, s. 98. Por. do tego szereg Norwidowskich odwołań do filozofii Diogenesa z Synopy: A. ZıoŁowicz, W stronę Diogenesa. Z problemów Norwidowskiej koncepcji kultury, „Wiek XIX. Rocznik Towarzystwa Literackiego im. Adama Mickiewicza” 2015, s. 359-378.

${ }^{29}$ J. Pistelli, Thomas Carlyle, „Sartor Resartus”, John Pistelli, https://johnpistelli. com/2015/01/13/thomas-carlyle-sartor-resartus/ [online], (dostęp: 22.11.2018).
} 
rozbiorowi właśnie poprzez „diabelską” szaradę z Sartora Resartusa i dają się (w większości) sprowadzić do wyartykułowanej przez Bishirjiana maksymy.

W Tajemnicy lorda Singelworth, ,ażeby usunąć nieco falangę kału” należy „całą falangę ludzi zdegradować” (DW VII, 230). Nieczystość jest jednak fiksacją nie tylko lorda, ale także tych, którzy go obmawiają lub opisują, jak Toni di Bona Grazia. Ksantypa przywoływana przez Singelwortha „wylewa z okna” na czoło Sokratesa „urnę pełną domowych nieczystości” (DW VII, 231). Improwizator wenecki ironizuje z kolei, jak to możliwe, aby „ktoś nad najznakomitszymi na świecie miejscami dlatego tylko unosił się, ażeby tam warunków poziomych higieny dopełniał... ażeby (mówię) splunąt z góry!..." (DW VII, 122).

Chciałoby się w tej sytuacji powiedzieć jedynie tylko, że oto Carlyle'owski paradoks „God-born devil's excrements” został przez starego Norwida „rozłożony do podstaw”, jeśli nie „rozproszony”, a może nawet i „zdekonstruowany” w obliczu śmierci autora Sartora Resartusa. Via posthuma - doszło tu do rozliczenia z Carlyle'em, nie da się jednakże ukryć, że to, co miało być rewizją i rozrachunkiem, wydatnie zachowało architekturę kunsztownej reminiscencji, bowiem Carlyle jest w Tajemnicy lorda Singelworth obecny dużo widoczniej aniżeli w Promethidionie (w którym na dobrą sprawę zachował swoje miejsce wyłącznie w planie istotnej skądinąd dygresji z dialogu Wiesław).

Chyba że - co do wspomnianej, wzmiankowanej dygresji - uznamy ją mimo wszystko za ważny horyzont prezentowanego w $1851 \mathrm{r}$. dialogu. To przecież swoisty przyczynek do Norwidowskiej genealogii „szatana-krwawca” (określenie z Promethidiona, DW IV, 128), więc na swój sposób istotny, rozrachunkowy punkt w dookreślaniu rozległego planu metafizycznego całego utworu. Czy nie może być to tym samym wyraźna, wyraźniejsza niż przewidywaliśmy, manifestacja Carlyle'owskiego tematu „kału diabła” z Sartora obecnego w ,piętrowanych perukach" i ,korkach twardych” jak szatańskie kopyta (DW IV, 129)? Rozpoznanie tego rodzaju nie było dotychczas w badaniach nad Promethidionem obecne, czy choćby i sugerowane, nawet w erudycyjnych passusach poświęconych dokładnie tej dygresji z poematu, takich jak te ze studium Anny Kadyjewskiej, „Świata - tego ksiażę”. O Norwidowskich obliczach szatana ${ }^{30}$. Warto by tymczasem tego rodzaju więź intertekstualną rzeczywiście zaryzykować, w jej świetle bowiem wielki poemat Norwida może jawić nam się także jako wielkie rozliczenie intelektualne swojego czasu - i w tym wymiarze odczytania, szczególnie po lekturze Wiesława - stanowić swoistą odpowiedź na Sartora Resartusa, wręcz być (cum grano salis) Norwidowskim ,anty-Sartorem Resartusem”.

\footnotetext{
${ }^{30}$ A. KADYJEWSKA, „Świata - tego ksiązęe”. O Norwidowskich obliczach szatana, „Studia Norwidiana” 17-18: 1999-2000, s. 21-48.
} 
Nawet niektóre tropy badaczy dotyczące Tajemnicy... także nieoczekiwanie zatrzymują się na polu wątków Carlyle'owskich. Marek Adamiec w studium Tajemnica lorda Singelworth albo metafizyka balonu wskazuje na dające mu do myślenia zbieżności w konstrukcji bohatera tytułowego, zaistniałe pomiędzy nowelą Norwida a Żywotem i myślami Zygmunta Podfilipskiego Józefa Weyssenhoffa $^{31}$. Samego Weyssenhoffa tymczasem zainspirować miał do stworzenia Podfilipskiego wzmiankowany już polski przekład Sartora Resartusa Sygurda Wiśniowskiego ${ }^{32}$.

„Nie ulega wątpliwości, że zgasły w $1881 \mathrm{r}$. Tomasz Carlyle był fenomenalnym człowiekiem i autorem" ${ }^{, 33}$, pisze o nim Wiśniowski w dwa lata po śmierci. Jako wielką osobowość, z którą jego filozofię szaty warto negocjować oraz dyskutować, postrzegać musiał Carlyle’a Norwid, zwłaszcza pisząc Tajemnicę... Mając jednak niespełna 30 lat, a więc pisząc Promethidiona, Carlyle'owskiej filozofii szaty wyrażającej horyzont głębokiej, laickiej metafizyki przeciwstawiać Norwid mógł (bezkompromisowo) „filozofię szaty Jezusowej”, jak wskazuje niebezpośrednio, lecz chyba dość jednoznacznie dialog Wiesław. Była to co prawda nierozwinięta w planie całego dialogu intuicja, zyskująca zaledwie swój skąpy zakrój w odpowiednim przypisie poety do poematu i w tej postaci wyrażała jednakże doskonale temperament polemiczny, potępiający wręcz - młodego Norwida, a także skalę jego oburzenia, wówczas gdy ujrzał (jak wierzę, jak podejrzewam: już w młodości) świat przez zabrudzony okular Carlyle’a, okular Teufelsdröckha, okular „God's born devil excrements”.

\footnotetext{
${ }^{31}$ M. ADAMIEC, Tajemnica lorda Singelworth albo metafizyka balonu, „Studia Norwidiana” 3-4: 1985-1986, s. 202.

${ }^{32}$ Tak jak Teufelsdröckh spisuje swój traktat o filozofii szaty, Podfilipski stwarza rozprawę Le Franc-Parler d'un Gentilhomme. Jak wskazuje Irena Szypowska, „wprowadzenie do powieści oryginalnej, «naukowej» rozprawy Podfilipskiego jest także zabiegiem, w którym ujawnia się ironiczna postawa narratora. Le Franc-Parler d'un Gentilhomme jest bowiem świadectwem intelektualnego poziomu bohatera, dowodem ignorancji i powierzchowności «filozofa»”. I. SzYPOWSKA, „Przewrotny panegiryk”. Autokompromitacja bohatera, [w:] TAŻ, Weyssenhoff, Warszawa 1976, s. 92

${ }^{33}$ S. WIŚNIOWSKI, Charakter i pisma, s. 50.
} 


\section{BIBLIOGRFIA}

Bratkowski S., Wstęp, [w:] R.W. EMERSon, Eseje, przeł. A. Tretiak, wstęp S. Bratkowski, t. I, Lublin 1997, s. 5-28.

Brzozowski S., Literatury zachodnie, [w:] TENŻE, Legenda Młodej Polski. Studia o strukturze duszy kulturalnej. Redakcja II, t. I: opracowanie tekstu: J. Bahr, współpraca: S. Góra, t. II: opracowanie tekstu: T. Podoska, Kraków 1997, s. 286.

Brzozowski S., Polskie Oberammergau, [w:] Legenda Młodej Polski. Studia o strukturze duszy kulturalnej, t. I, s. 181.

Brzozowski S., Wobec literatury rosyjskiej, [w:] Legenda Młodej Polski, t. II, s. 349.

BurdzIEJ B., „Wedle rozmaitości zmiennej kalendarza”. Norwid „przemyślony”, „Studia Norwidiana" 34: 2016, s. 187-227.

CARLYle T., Sartor Resartus. On heroes, hero worship, introduced by W.H. Hudson, London 1948.

CARlyle T., Sartor Resartus. Życie i zdania Pana Teufelsdröckha $w$ trzech księgach, przeł. S. Wiśniowski, Warszawa 1882.

CORLISS JR. F., Norwid and the American Transcendentalists, [w:] Cyprian Norwid. 18211883. Poet, thinker, craftsman. A centennial conference, ed. by B. Mazur and G. Gömöri, London 1988.

DambeK-Giallelis Z., Tajemnice „,Tajemnicy lorda Singelworth”, „Studia Norwidiana” 35 : 2017, s. 185-198.

GöMÖRI G., Cyprian Norwid's Image of England and America, „The Polish Review” 46(2001), no. 3, s. 271-281.

HalkiEwiCz-SojaK G., Norwidowska legenda o Byronie. Refleksy legendy w innych utworach Norwida, [w:] TAŻ, Byron w twórczości Norwida, Torun 1994, s. 106-117.

KADYJEWSKA A., „Świata - tego książę”. O Norwidowskich obliczach szatana, „Studia Norwidiana" 17-18: 1999-2000, s. 21-48.

LiJewsKA E., Kuzynki Norwida. Euphemia Tudor Kleczkowska i Ketty KleczkowskaKierkpatrick, „Studia Norwidiana” 34: 2016, s. 169-185.

MaŁecKa A., Carlylean inspirations in Polish modernist philosophy, Kraków 1993.

SZYPOWSKA I., „Przewrotny panegiryk”. Autokompromitacja bohatera, [w:] TAŻ, Weyssenhoff, Warszawa 1976, s. 92-96.

Trojanowiczowa Z., DambeK Z., Kalendarz życia i twórczości Cypriana Norwida, t. I: 1821 1860, Poznań 2007.

TRYBUŚ K., Maska lorda Singelworth, „Studia Norwidiana” 14: 1996, s. 95-103.

WIŚNIOWski S., Charakter i pisma Tomasza Carlyle'a, „Ateneum. Pismo naukowe i literackie" 1(1882), s. 50-69, 269-297. 


\title{
SPÓR O FILOZOFIE SZATY. CYPRIAN NORWID A THOMAS CARLYLE
}

\author{
S t r e s z c z e n i e
}

Stosunek Cypriana Norwida do wyłożonej przez Thomasa Carlyle’a w powieści Sartor Resartus filozofii szaty może co prawda wydawać się wyłącznie przedmiotem spekulacji, jednak nie ulega wątpliwości, że z Carlyle'em autor Vade-mecum zetknąc się musiał (o czym zaświadczają jego wykłady o Juliuszu Słowackim). W niniejszym studium kreślę dwa obszary możliwej intertekstualnej wspólnoty motywów Norwida z filozofią oraz legendą życia Carlyle'a: jedną wyznacza poemat Promethidion oraz fragment dialogu Wiesław mogący stanowić formę polemiki poety z Carlyle'owską filozofią szaty; drugą natomiast określa Tajemnica lorda Singelworth, w której sylwetka i postawa życiowa tytułowego bohatera noweli mogłyby zdradzać ekstrawagancje samego Carlyle'a (domniemanie wzmacnia fakt śmierci Carlyle'a w 1881 r., a więc w czasie pisania tzw. nowel włoskich).

Słowa kluczowe: Cyprian Norwid; Thomas Carlyle; Sartor Resartus; Promethidion; Tajemnica lorda Singelworth.

\section{DISPUTE OVER THE PHILOSOPHY OF CLOTHES. CYPRIAN NORWID VERSUS THOMAS CARLYLE}

\section{S u m m a r y}

Cyprian Norwid's attitude to the philosophy of clothes presented by Thomas Carlyle in Sartor Resartus may indeed be perceived only as an object of speculation, but undoubtedly the author of Vade-mecum author must have encountered Carlyle (as confirmed in his lectures on Juliusz Słowacki). In this study I outline two areas of potential intertextual community of Norwid's literary motives with the life's philosophy and life's legend of Carlyle: one is delimited by the poem Promethidion and a fragment of the dialogue Wiestaw, which may be a kind of polemic with the Carlylean philosophy of clothes; the other area is delineated by Lord Singleworth's Secret, where the figure and life's attitude of Singleworth could easily reveal the eccentricities of Carlyle himself (this supposition is corroborated by Carlyle's death in 1881, thus in the time of Norwid's writing so-called Italian novelettes).

Key words: Cyprian Norwid; Thomas Carlyle; Sartor Resartus; Promethidion; Lord Singleworth's Secret.

KAROL SAMSEL - doktor habilitowany, adiunkt w Instytucie Literatury Polskiej Wydziału Polonistyki Uniwersytetu Warszawskiego. Kierownik Pracowni Historii Dramatu 1795-1939 przy ILP UW. Publikował swoje teksty w „Pracach Filologicznych”, „Pamiętniku Literackim”, „Studiach Norwidianach” oraz w „Yearbook of Conrad Studies (Poland)”. Autor monografii Norwid-Conrad. Epika w perspektywie modernizmu (Warszawa 2015) oraz Inwalida intencji. Studia o Norwidzie (Warszawa 2017). 